\title{
Life-Long Work or Well-Deserved Leisure in Old Age? \\ Conceptions of Old Age Within the French and German Labour Movements in the Late Nineteenth and Early Twentieth Centuries ${ }^{1}$
}

\author{
KAREN SCHNIEDEWIND
}

\begin{abstract}
Summary: The close connection between old age and retirement and to what extent society accepts work-free retirement in old age emerged as the topical themes we know in France and Germany as late as the 1950s and 1960s. By analysing the relevant discussions in the labour circles of both countries the author examines whether this modem concept of retirement originated in the early phase of the welfare state. The concepts and points of criticism which each of the labour movements developed for old age provision show, by virtue of the different national mental attitudes, that their considerations about old age as a life phase diverged from one another to a great degree. The German labour movement believed that old age pensions were primarily a compensation for the reduction in income on reaching an advanced age, and it thus gave preference to the invalidity pension. In contrast, French society supported the idea of welfare security for the old. Along with criticisms of state social policies, the purpose of providing for the old is at the centre of the essay's analysis, more specifically the contrary forms this discussion took in Germany and France: obliged to work in old age or well-earned retirement.
\end{abstract}

Current debates on problems relating to old age and pensions are characterized by the close association between pensions and retirement. Nowadays, the concept of retiring is not inevitably linked to old age, frailty or needing to be cared for in old age, but can, in times of economic crisis, commence at such a relatively early stage (early retirement Vorruhestand) that the twinning of old age with infirmity seems to have lost much relevance. However, the ongoing discussions concerning prolonging the working life in order to ease the financial claims on the various state pension schemes have never questioned that retirement is a phase of life in its own right; rather, it is commonly seen as the last stage in modern

I This essay is based on the results of a research project ("Altersbilder und Sozialpolitik fulr das Alter in Deutschland und Frankreich, 1900-1945") at the University of Bremen (Sonderforschungsbereich 186, "Statuspassagen und Risikolagen im Lebenslauf"), directed by Heinz-Gerhard Haupt and Gerd Göckenjan.

International Review of Social History 42 (1997), pp. 397-418 
biographies, the period of finally departing from paid employment, that chapter in the life cycle when one is relieved of the strains and stresses of work and can begin to build one's free time around "meaningful" activities.

Such concepts of retirement were developed in the German Federal Republic relatively late, primarily in the wake of the great pension reform of 1957, which established for the first time that a pension, as a goal for society as a whole, should cover living costs, thus making work-free retirement the rule for all. ${ }^{2}$ In France as well, the actual realization of a financially secure basis for retirement was attained for the majority of the population only in the post-war period: the Sécurité Sociale (1945) system of a basic pension was supplemented by different forms of state subsidies until this complementary function was taken over gradually by the various additional systems within pension cover. ${ }^{3}$ When and how did this combination of age and retirement develop, a constitutive element of all industrial societies in Western Europe and North America? How did society as a whole grow to accept a life phase in old age for all its members, a period free of the necessity to earn a living? This question is of special interest, as the mentality of the time, particularly in Germany, collided with earlier cultural opinions. How this development proceeded depended on various national characteristics, and it can be deduced from analysing the national debates of the day concerning old age, retirement and paid work. Germany and France are the examples under scrutiny here.

A pension in lieu of salary and available to all presupposes that society will always have sufficient financial resources. Nevertheless, the changes in attitude to this question cannot be ascribed solely to the economic advancement or prosperity of society. We therefore start from the viewpoint that the different forms of social policy adopted in Germany and France have resulted from the extent to which old age was seen in both countries as a phase of life for which the state had to provide. Such social legislation, we hold, is an expression of how respect for the aged is evaluated, attitudes which reflect certain cultural traditions in their national particularities. Not only the various ways of dealing with the phenomenon of old age, but also the attitude to the opposites work-leisure is of interest in connection with the problems of retirement. In the following pages, then, we are not concerned with presenting the chronology of state legislation in both countries, nor with a comparative description of different processes of institutionalization, or even with contrasting the material conditions under which old people lived in Germany and France. Instead,

2 For the development of social policy in the post-war era see the study by Hans Gunther Hockerts, which concentrates on politics and the history of institutions: Sozialpolitische Entscheidungen im Nachkriegsdeutschland: Alliierte und deutsche Sozialversicherungspolitik (Stuttgart, 1980).

${ }^{3}$ See Anne-Marie Guillemard, Le déclin du social. Formation et crise des politiques de la vieillesse (Paris, 1986). 
discursive elements constitute the core of the analysis: controversies about old age pensions and concepts about that separate stage of life called retirement.

With this choice of main focus the investigation differs from previous studies about ageing, the history of pension insurance and how retirement came to be considered a separate stage in life. Christoph Conrad's comprehensive monography on this subject is restricted to Germany and places other themes at the centre of the study - demography and families, an estimation of Poor Law and Social Security legislation, an analysis of socio-political publications. ${ }^{4}$ For France there is the detailed investigation by Bruno Dumons and Gilles Pollet on the genesis of the first French old age pension scheme (1910), a study which delineates the positions taken up by different social groups. Sandrine Kott, on the other hand, devotes attention to the entire German social insurance system; ${ }^{6}$ in this connection she presents the difference between the ideological concepts "German community" and "French solidarity", which, in her opinion, lay behind the particular legislation in these countries.

The aims of this essay are set in a narrower and broader context, namely to compare widely held opinions in both countries, while simultaneously investigating social policy only in respect of old age, and, finally, what the labour movement's concepts of old age in the life cycle amounted to. On this basis the national differences can be clearly presented. The attitude of the labour movement is central to our arguments, for two reasons. First because the achievement of a legally recognized right to retirement was intrinsically linked to the existence of large groups in society who, on account of their economic situation, were not capable of making provisions for old age. Second, it could be expected that the labour movement, as the decisive oppositional force in politics at the turn of the century, would develop views on this subject which deviated from the conventional wisdom of the time.

The following therefore concentrates on the attitudes of the workers' parties and the trade unions to the projects of old age insurance which had been developed up to World War I. In the rejection of old age insurance legislation (Retraites ouvrières et paysannes) of 1910 by a majority of French workers and the - temporary - opposition of German Social Democracy to the Old Age and Invalids' Insurance Act of 1889 the GermanFrench differences manifest themselves more clearly than in any

4 Christoph Conrad, Vom Greis zum Rentner. Der Struktunvandel des Alters in Deutschland zwischen 1830 und 1930 (Götingen, 1994).

${ }^{3}$ Bruno Dumons and Gilles Pollet, L'Etat et les retraites. Genese d'une politique (Paris, 1994).

- Sandrine Kott, L'Etat social allemand: Représentations et pratiques (Paris, 1995).

'Sandrine Kott, "Gemeinschaft oder Solidarität? Unterschiedliche Modelle der französischen und deutschen Sozialpolitik am Ende des 19. Jahrhunderts", Geschichte und Gesellschafi, 3 (1996), pp. 311-330. 
estimation of the old age pension schemes of the inter-war period which met majority acceptance in both countries. Our analysis of the positions taken up by the German labour movement is based mainly on texts published by the SPD and German trade unions, those organizations which, especially in Wilhelmine Germany and also in the Weimar years, represented the great mass of German workers and influenced them greatly in turn. Because of the fissured state of the French labour movement a variety of periodicals had to be consulted in order to reflect the wide range of opinions. In doing so, however, the purpose is not to describe in any detailed way the stand taken by the various groupings against the old age insurance law of 1910 , or to undertake an evaluation on the basis of the radicalism of the standpoints, but rather to prove the widespread presence of definite views within the French labour movement on provision for old age, views which we do not find in the German press of the period.

This essay is divided into two parts. In the first half the central theme is the criticism voiced by both labour movements against state systems of insurance for the aged. Besides describing the various objections from the labour side, light is shed on the principles behind such arguments, including their significance. On this basis the central question is posed once more, namely what was the real aim, from the point of view of organized labour, of old age insurance. Finally, the opposing twin concepts "lifelong work" or "well-deserved leisure in old age" are discussed.

\section{CRITICISM OF STATE INSURANCE SCHEMES FOR THE AGED}

At the end of the nineteenth and the beginning of the twentieth century the "social question" in both Germany and France had made the search for socio-political solutions a topical subject. Despite this similarity, both countries differed greatly from each other in the degree of industrialization and urbanization, as well as in demographic trends. Until well into the twentieth century France's population was predominantly agrarian. The balance shifted to a slight urban majority only in $1931 .^{8}$ In 1911,42 per cent of all jobs were in the agriculatural sector; in cities and towns small firms were dominant in giving employment. ${ }^{10}$ In contrast, 60 per cent of Germans lived in urban areas by $1910, "$ ten years earlier those employed in factories or as skilled artisans surpassed numbers in agriculture. ${ }^{12}$ As

Serge Bemstein, La France des années 30 (Paris, 1991), p. 17.

- Christophe Charle, Histoire sociale de la France an XIXe siècle (Paris, 1991), p. 142.

10 Heinz-Gerhard Haupt, Sozialgeschichte Frankreichs seit 1789 (Frankfurt/Main, 1989), p. 267.

"Hans-Ulrich Wehler, Deutsche Gesellschaftsgeschichte. Dritter Band: Von der "Deutschen Doppelrevolution" bis zum Beginn des Ersten Weltkrieges 1848-1914 (Munich, 1995), p. 512.

12 Ibid., p. 619. 
regards demographic tendencies, France had a lower birth-rate, ${ }^{13}$ which led to a comparatively higher proportion of the aged within the population. In 1900 , persons over 65 years constituted 8.2 per cent of French society, but only 4.9 per cent in Germany. ${ }^{14}$ Between these social parameters discussion about providing for the aged was conducted in both countries.

The first stage in German pension insurance was marked by the law of 1889 goveming insurance in old age and invalids' pensions. Here the emphasis was primarily on the risks of invalidity, but the law also held out the prospect of a state pension on reaching the 70th birthday. Those insured included all employees who earned less than 2,000 Marks annually. The self-employed of modest means could also join the scheme on a voluntary basis. After decades of discussion the first law on old age insurance was passed in France as late as 1910, but provided for cases of invalidity to a very limited degree. In the French provisions factory workers and artisans, as well as agricultural labourers and tenant-farmers, were covered. Although the French labour movement was also principally in favour of a state pension system, many workers of both sexes, and the organizations which represented them, felt that the bill's shortcomings justified its rejection. In contrast to Germany, the French pension legislation was opposed by a broad front of critics, consisting of workers, portions of the middle class and most small businessmen. Especially critical of the new law for the aged were those workers organized in the CGT (Confédération Générale du Travail), which at that time was under strong anarchist influence. Despite the relatively low proposed age of 65 years for pension entitlement, this section of the labour movement described the bill as "a law for the dead" ("une loi pour les morts"), and succeeded, by political agitation, in having the age limit subsequently reduced to 60 . Opposition also formed against modes of contribution and capital cover, termed as "legal robbery" ("un vol législatif"). The principle of workers contributing directly to the scheme proved to be another central element in the French labour movement's rejection of the legislation. ${ }^{15}$

By boycotting the new law to a substantial degree, French workers and employers sabotaged the regulations goveming compulsory insurance against invalidity and old age, with the result that being covered under the new law remained the individual's personal decision. From the 12 million

13 Hartmut Kaelble, Nachbarn am Rhein: Entfremdung und Annaherung der französischen und deutschen Gescllschaft seit 1880 (Munich, 1991), pp. 42-43.

14 Patrice Bourdelais, Le nouvel âge de la vieillesse: Histoire du vieillissement de la population (Paris, 1993), p. 175.

is See the detailed description of the opposition in Irène Bourquin, "Vie onvrière" und Sozialpolitik: dic Einfihrung der "Retraites ouvrières" in Frankreich um 1910: Ein Beitrag zur Geschichte der Sozialversicherung (Bem, 1977), p. 277; Gérard Noiriel, "'L'EtatProvidence' et 'colonisation du monde vécu': L'exemple de la loi de 1910 sur les Retraites Ouvrières et Paysannes", Prévenir, 19 (1989), pp. 99-112; on the different motivation of opponent groups in society see Henri Hatzfeld, Du paupérisme d la Sécurité sociale 1850 1940: Essai sur les origines de la Sécurité sociale en France (Paris, 1971). 
who should have been legally insured only 7.5 million were covered by the end of 1912; from the 6 million who were legally entitled to join the scheme voluntarily only 750,000 did so. In the years 1912-1914 merely one-third of workers registered under the legislation were paying contributions. ${ }^{16}$ It was mainly the older workers who made use of the new law and profited from its favourable interim regulations; in 1912, almost half of the insured were over 50 years of age. ${ }^{17}$

In like manner, the German Social Democrats initially put up determined resistance to the Old Age and Invalids' Insurance Act of 1889. They maintained that it was just Poor Law legislation under another name. ${ }^{18}$ They also demanded the lowering of the age of entitlement to 60 years, the reduction of the work-span leading to eligibility from 30 to 20 years and an increase in pension levels. ${ }^{19}$ From 1889 onwards, however, when the SPD Reichtagsfraktion voted in favour of an amendment to the social insurance law, the party adopted a more positive attitude to official social policy. Legal provisions for the old and incapacitated were no longer questioned in principle; unlike the situation in France, broadly based opposition to such measures did not exist in Germany. After initial procrastination, the SPD gave a warm welcome to laws relating to invalidity and directed their policy to making suggestions as to how existing legislation might be improved. "If we want to change the law, we have to make sure that the people will find it easier to have their incapacity claims recognized; there must be a change in entitlement rules in connection with invalidity claims, but not in cases of old age pensions. The pension should be awarded when the capacity to work has been impaired by one half or two thirds." So ran the demands of Heinrich Molkenbuhr, the SPD expert on social policy, in $1904 .^{20}$

\section{Old Age or Partial Invalidity}

As mentioned earlier, the French age of entitlement for old age pensions, set at 65 years, provoked fierce and widespread opposition. Demographic calculations underlined this criticism. It was stated that 95 per cent of all workers would never reach the age of entitlement:

${ }^{16}$ Bruno Dumons and Gilles Pollet, "La Naissance d'une politique sociale: les retraites en France (1900-1914)", Revue Française de Science Politique (1990), pp. 629-648, esp. p. $642 f$.

${ }^{17}$ Ibid., p. 646.

18 August Bebel, "Das Gesetz uber die Invaliditäts- und Altersversicherung im Deutschen Reich", Die Neute Zeit, 7 (1889), pp. 385-400 and 454-473, esp. p. 393.

${ }^{19}$ Die Sozialdemokratie im Deutschen Reichstag (Berlin, 1909), pp. 416-417.

20 Molkenbuhr's statement to the Parteitag (Bremen, 1904), in Wilhelm Schröder, Handbuch der sozialdemokratischen Parteitage von 1863 bis 1909 (Munich, 1910), p. 50. 
For the moment, the inconvertible fact is that the working class must deduct nine francs a year out of their meagre wages (15 francs when the husband and wife are factory workers) for a pension which 95 per cent of them will never draw. ${ }^{21}$

Critics of the legislation argued that the beginning of the pension age should be set low enough so that most workers would live to experience it. Although the German Social Democrats, too, originally argued for a reduction of the pension age ${ }^{22}$ which had been set at 70 in 1889 , their attitude was somewhat revised by Heinrich Molkenbuhr in an article in Nelue Zeit at the turn of the century. He referred to "the enormous burden imposed on industry by agriculture" 23 should the main emphasis be placed on old age pensions and a reduction of the pensionable age. As the life expectancy of rural labourers was higher than that of industrial workers in the nineteenth century, Molkenbuhr feared that, in the event of a lowering of the pension age, the greater part of the contributions needed to finance the system would be expended for the payment of agricultural labourers' pensions. And when a delegate at the SPD annual conference of 1904 moved a motion requesting the Reichtagsfraktion of the party to press energetically for a reduction in the pensionable age, Molkenbuhr argued against it:

A more unsuitable demand than this on the Old Age and Invalidity Law can hardly be proposed. If this claim is put into practice the industrial workforce will suffer grave disadvantages. If a worker is unfit for work he receives the invalidity pension he needs. However, should he be considered still fit for employment and earns as much as others in comparative jobs, his wages will be cut to the amount of the pension he receives. ${ }^{24}$

Reducing the pensionable age, the argument continued, meant in effect the subsidization of large landowners. Molkenbuhr's intervention led to the motion's defeat. In subsequent years, the SPD adhered to official government policy and gave preference to insuring workers against the risks of invalidity. The SPD thus demanded an extension of the incapacity pension scheme and more or less ignored the plight of old age pensioners.

Such decisions show clearly how the SPD concentrated its efforts primarily on representing the demands of those sections of industrial labour situated in urban centres. Playing the interests of land workers off against

21 A. Merrheim, "Les Retraites ouvrières et le Projet de loi", Le Mouvement socialiste (January 1910), pp. 21-45, esp. p. 45. See also Gustave Hervé, “Dans la rue! Bluff électoral", La Guerre sociale, 2 (December 1909), p. 1.

22 "However, the majority [in the Reichstag] has rejected all motions on the lowering of the pension age, so that the old age pension is, and will remain, merely a 'decoration' of the law. Only a few chosen ones will receive it, and they will not be embarrassed by the pension amount." Bebel, "Das Gesetz uber die Invaliditäts- und Altersversicherung", p. 461.

${ }^{23}$ Heinrich Molkenbuhr, "Zum französischen Altersversicherungsgesetzentwurf", Die Neure Zeit, 42 (1900-1901), pp. 492-499, esp. p. 495.

${ }^{24}$ Schröder, Handbuch der sozialdemokratischen Parteitage, p. 49. 
those working in cities and towns did not arise during similar discussions in France. The different approach adopted there is certainly an expression of the grades of industrialization attained and the resultant social structures present in both countries. Because of France's predominantly agricultural structure $^{25}$ it was impossible to relegate the wishes of rural labour. Furthermore, the risk of invalidity due to industrial accidents was probably much lower than in Germany. In France, artisan workshops and small businesses characterized the scale of industrialization. In 1901 over 80 per cent of firms were run by the owner and his family. ${ }^{26}$

The risk of invalidity was therefore considered to be an exception in France. In German legislation provision for workers' retirement had the same status; old age was seen as a special form of incapacity which had to give preference to invalidity status granted during the working life of the individual. The priority which the concept of old age enjoyed in French law can be partly explained by the demographic structure of the population. The proportion of elderly persons was far higher than in Germany, ${ }^{27}$ and the question of pensions for the aged had therefore more political urgency.

\section{Insurance or Welfare Principle}

As we have seen, the criticism voiced by Germany's Social Democrats against old age and invalids' insurance stated, at least in its initial phase, that the legislation merely prolonged Poor Law measures under a different heading: "[The law] was nothing but a substitute, another label, for an equally miserable and low level of support for the poor. ${ }^{28}$ Merely those efforts to abolish the "degrading" character of Poor Law measures as proposed in the new legislation found acceptance - the recipient of an old age pension no longer lost citizenship or the right to vote, thus lessening the stigmatization of the poor. Furthermore, drawing a pension from an insurance fund was not a disgrace; those who benefited from it could not be branded as idlers. However, as the pensions paid were sometimes even lower than the Poor Law assistance and fell therefore far short of the existence minimum, workers would need Poor Law support in the future as well. The so-called benefit of the old age pension obviously did not last long. ${ }^{29}$ The generally negative attitude of the SPD was of equally short duration.

\footnotetext{
25 Charle, Histoire sociale de la France, p. 142.

26 Haupt, Sozialgeschichte Frankreichs, p. 267.

27 Bourdelais, Le nouvel age de la vieillesse, p. 175. This background explains the privileged status accorded to old persons who had raised several children in the French Old Age Pension Law of 1910. See Karen Schniedewind, "Soziale Sicherung im Alter. Nationale Stereotypen und unterschiedliche Lösungen in Deutschland und Frankreich in der ersten Hälfte des 20. Jahrhunderts", Francia, 21 (1995), pp. 1-22.

28 Bebel, "Das Gesetz uber die Invaliditats- und Altersversichenung", p. 267.

29 lbid., p. 455.
} 
In contrast to developments in Germany where the law of 1889 in respect of providing for the aged had shifted the emphasis from public welfare to pension insurance, a law was passed by the French parliament in 1905 on the assistance to be given to elderly, infirm and incurably ill persons without means (L'assistance obligatoire aux vieillards, aux infirmes et aux incurables privés de ressources). Old people from 70 upwards were recognized as a separate category entitled to assistance. Those over this age limit had to prove their neediness, but, as the law of 1907 pronounced, not their lack of physical capacity, because "at this age the man has paid his debt of work and all that is left is to examine whether or not he is devoid of means". ${ }^{30}$ On the basis of this law France's elderly poor now had a legally underwritten right to state assistance. This diminished the stigma of being poor, without removing it entirely. ${ }^{31}$ From the moral responsibility of society towards the individual (as formulated during the French Revolution) grew an entitlement which he or she could claim from the state. Wide sections of the population, including part of the labour movement, reacted positively to the new law. In 1908, for example, the independent Revue socialiste published two articles appreciative of the recently passed law. The bill's contents were welcomed in principle, but the writers of the articles found fault with the law's execution and the dangers of abuse. Despite all critical points raised, however, the new law was enthusiastically proclaimed as "the finest demonstration of solidarity passed by Parliament in France since its inception". ${ }^{32}$

The idea that persons who had reached a certain advanced age and were living in needy circumstances should receive state support whether they were capable of further physical labour or not was unheard of in the German Poor Law system. The elderly poor of Germany were subjected to general rules of assessment and were, as such, not explicitly mentioned as being in need of assistance, nor were they favourably treated in the amount they received. ${ }^{33}$ Social provisions for the aged enjoyed a long

${ }^{30}$ Edouard Cheval, Les résultats pratiques de la loi du 14 juillet 1905 sur l'assistance obligatoire aur vieillards, aux infirmes et aux incurables privés de ressources (Chambéry, 1911), p. 12.

${ }^{31}$ The contemporary regulations conceming official and private assistance for the poor were also depicted in France as humiliating and demoralizing. In some areas the elderly recipient lost the right to vote on entering a hospice: Emile Landrin, "L'Assurance sociale et l'assistance", Le Mouvement socialiste (August 1903), pp. 561-570, esp. p. 563.

${ }^{32}$ Joseph-Baptiste Bouhey-Allex, "La loi d'assistance du 14 juillet 1905", La Revue socialiste (July 1904), p. 32-43, esp. p. 43; Jean Neybour, "Une expérience sociale. La loi d'assistance du juillet 1905", La Revue socialiste (March 1908), pp. 237-247.

${ }^{33}$ See Gerd Göckenjan, "Alter und Armut. Armenpflege fur alte Leute", in idem (ed.), Recht auf ein gesichertes Alter? Studien zur Geschichte der Alterssicherung in der Frühzeit der Sozialpolitik (Augsburg, 1990), pp. 105-141; Karen Schiedewind, "L'assistance aux vieillards en France et en Allemagne à la fin du XIXe et au début du XXe siècle". Actes duc Colloque sur la loi du 15 juillet 1893 instituant l'Assistance médicale grasuire, Grenoble, 1993 (forthcoming, 1997). Emminghaus notes that public assistance for the aged poor in nineteenth-century Paris was graded: 70 year olds received five Francs 
tradition in French politics. During the French Revolution it was postulated that all members of society should be guaranteed an adequate standard of living, either by creating jobs for them or by state support for those who were not capable of earning their living. Many decrees dealt explicitly with assistance for the elderly, either directed against pauperism amongst the old, or as attempts to insure that support in the phase of old age should become an individual right. The payments laid down, however, were so low that the state knew that private provisions for old age would continue. ${ }^{34}$ Many of the projects hatched during the revolutionary years failed for lack of funds, and their realization came only during the Third Republic. ${ }^{35}$

Nevertheless, essential and enduring ideas at solving the problem had been laid in the 1790s. During the nineteenth century reference was made again and again to the "sacred responsibility" for the old (dette sacrée) and came to inform the debates around the law of 1905 .

These republican ideals permeated the labour movement as well. They may also have contributed to the fact that the duties of employers, and of society as a whole, towards elderly workers of both sexes and old people generally in need found a more radical expression in France than in Germany. This historical development was delineated by Rouanet in Revue socialiste (1901):

The truth is that the development of altruistic feelings in a minority of thinkers who were hurt by the spectacle of the drudgery of the working class, hand in hand with the development of the workers' consciousness as they became more aware of the social importance of their rôle in production, gave rise, from the first half of the nineteenth century onwards, to the concept of the right to a pension in a worker's old age. ${ }^{36}$

As regards providing for the aged, the republican ideal of society's responsibility for its needier members dovetailed with the demands of the French labour movement for adequate financial assistance for those who spent their lives serving the common good. German labour circles had no comparable tradition to revert to. The German laws providing assistance for the aged, and the debates within the labour movement which ensued, show the first sharp deviations from the French experience. In Germany,

monthly, those aged 79 to 82 eight Francs, ten Francs for the 82-84 year olds and 12 Francs for those over 84: Arved Emminghaus, Das Armenwesen und die Armengesetzgebung in europaischen Staaten (Berlin, 1870), p. 632.

3* The Comité de Mendicité had the task to combat the extensive begging of the time and occupied itself especially with the situation of the elderly. In Livre de Bienfaisance highest priority was given to assisting old agricultural labourers and tenant-farmers: Jean-Pierre Bois, Les vieux de Montaigne aux premières retraites (Paris, 1989), p. 244.

35 J.H. Weiss, "Origins of the French Welfare State. Poor Relief in the Third Republic 1871-1914", French Historical Studies, 13 (1983/1984), pp. 46-78, esp. pp. 47-48.

${ }^{36}$ Gustave Rouanet, “Les retraites ouvrières”, La Revue socialiste (September 1901), pp. 257-274, esp. p. 258. 
it had first to be established that assistance for the old was a social problem in itself. Any solutions offered followed even later.

Contrary to the situation in Germany, French society at the beginning of the twentieth century was not yet unanimous about ways to provide for the elderly. Should an insurance solution be chosen, as in Germany, which had the worker contributing financially to his own old age pension? Or should the state merely guarantee a basic maintenance amount, allowing private schemes to dominate in the provision of old age support as in the past? Seen in retrospect, the insurance model was held to be the modern one, and was subsequently adopted. ${ }^{37}$ In contrast, the French controversy can be seen as anticipating the discussion which later in Germany centred around the demand that the state had an obligation to ensure that each citizen was granted a subsistence level of welfare aid ${ }^{38}$ The French political scientist Didier Renard has also characterized this attitude as republican discourse, which dates back to the French Revolution and has strongly influenced all state projects for providing for the elderly up to the introduction of the Sécurité Sociale. ${ }^{39}$

\section{Financing Pensions}

Unlike the German experience, the criticism levelled by the French labour movement against the draft bill on state old age pensions rejected the principle of workers' contributions. On the one hand, reference was made to the low level of French wages at the time; on the other hand, the refusal to pay pension contributions was part of the more general negative stance to this section of the bill. This position was formulated in the magazine of a revolutionary socialist group, La Guerre sociale:

The workers rightly demand retirement benefits for pensioner relatives because the latter, having contributed by their labour to social wealth, have the right to expect an old age in which they could be at least adequately provided for. They consider that the amount of these pensions, however modest they may be, would nonetheless relieve a lot of the distress, and would bring some slight improvement to the lives of working families [...] It is legitimate that a little of the gold that the wage eamers sweat out for the propertied classes should redound to them. But

37 See Bruno Dumons and Gilles Pollet, "Les socialistes français et la question des retraites (1880-1914)", Vingtieme Siècle: revue d"hisfoire, 38 (1993), pp. 34-46. The authors imply that the French mentality was backward: for example, when they accuse the revolutionary socialists, who were against the insurance solution, of not being capable of thinking in modern terms (p. 39).

${ }^{38}$ This viewpoint was a result of Germany's economic crisis in the Weimar years. See Fritz Langer, "Sozialversichenung oder allgemeine Staatsburgerversorgung?", Die Glocke, 43 (1923), pp. 683-688.

39 Didier Renard, "Une vieillesse républicaine? L'Etat et la protection sociale de la vieillesse, de l'assistance aux assurances (1880-1914)", Sociétes Contemporaines, 10 (1992), pp. 9-22. 
to ask them to further whittle down their tiny share, is to make a mockery of them. ${ }^{40}$

In Le Socialiste, the central organ of the Parti Ouvrier Français, in which Jules Guesde played a leading role, it was argued that, because of his life-long exploitation and the surplus value he had created for the benefit of his employer and the state, the worker had a right to a pension. In short, all workers were entitled to a pension because they had made others rich, and the claims made on them to finance pension insurance had already been settled by virtue of the surplus value they had generated:

It must be the responsibility of society to support the older workers who have in their day provided millions and billions for the idle rich of Capitalism. ${ }^{41}$

This line of argument against (voluntary) contributions seems consistent and appropriate. The alternative forms of financing pensions debated at the time were either of the direct variety, i.e. making the employer pay the contributions in full, or indirect, by imposing a special tax on higher incomes. As early as 1904-1905, François Fournier, writing in the magazine $\mathrm{La} \mathrm{Vie}$ socialiste, made the case that all elderly workers had the right to sue their former employers for support in old age. ${ }^{42}$ Fournier's formulation was very general and represented more a moral right than a concrete demand, especially as the handing over of pension insurance into the hands of the employers could not be in the workers' true interest. Indeed, their experience of company pensions and how these served to maintain and consolidate paternalistic work relationships precluded serious consideration of such a solution. It seemed more promising to demand that workers' contributions to state pensions be replaced by a progressive income tax. Such a resolution was printed in Le Socialiste in 1901. These taxes, it was argued, should not be collected from the employers in question, as they would frequently succeed in passing on such costs to the workers, rather a tax should be "imposed indiscriminately on all the capitalists, who are all supported in their idleness, luxury and opulence by the labour of the workers". ${ }^{43}$ The entrepreneurs, as a whole, should carry responsibility for providing for the needs of their elderly employees.

A downright refusal to pay workers' contributions played no part in German deliberations, as, according to Prussian insurance legislation, such contributory payments were the precondition for allowing the workers to organize and administer such pension funds. That is why, as Herta Wolff

${ }^{40}$ Maurice Harmel, “Une 'grande' réforme. Retraites ouvrières", La Guerre sociale, 51 (December 1909), p. 3.

41 "Les retraites ouvrières", Le Socialiste, 32 (August 1901), p. 1.

42 François Fournier, "Retraites pour la vieillesse", La Vie socialiste (1904-1905), pp. 976-987, esp. p. 977.

43 "Les retraites ouvrières", p. 1. A corresponding draft bill fom Guesde was positively reviewed in La Guerre sociale. Maurice Harmel, "La comédie parlementaire - ou l'on parle des retraites ouvrières", La Guerre sociale, 4 (January 1911), p. 1. 
suspects, the demand to abolish workers' contributions was never made in Germany - for "tactical considerations". ${ }^{44}$ None the less, August Bebel did at one time consider the possibility of having the state subsidy to the pension schemes financed by a direct tax on wealth:

If the payment of the Reich subsidy were to be raised by imposing a direct, progressive tax on the well-off and the rich, then those persons would be drawn into the tax net who at present have to pay contributions only for a coachman, cook or other servants and have otherwise no tax obligations to worry about. ${ }^{45}$

In addition, Bebel pointed out that the Reich subsidy in the form hitherto enforced was a product of indirect taxation paid by the workers themselves and therefore could not be termed a "gift" or "Government charity". 46 Bebel's line of reasoning clearly demonstrates that he thought it quite legitimate that workers should contribute to state pension funds - but only on an equitable basis. According to him, the Reich subsidy should not be financed by the workers, but by "the well-off and the wealthy". Bebel also proposed for this class a just solution - the non-productive sector of the upper classes would have to pay proportionately more.

Whereas the labour movements of both countries shared a common - theoretical basis for political debate, namely Marx's theories of exploitation and surplus value, the implications reached were radical and logical only in the French case. ${ }^{47}$ The strategy of the German Social Democrats was imbued by the belief that the workers' movement was growing in influence; the policies adopted by the SPD were, in consequence, reformist.

\section{A Pension to Satisfy Basic Needs or the Subsidy Principle}

In reality, the old age pensions envisaged in both countries were conceived more in terms of a subsidy, which had to be supplemented by other forms of income or through private or state supportive measures. Savings, help from the family, a further term of (possibly part-time) employment or, in emergencies, recourse to Poor Law assistance - such components continued to constitute the essential elements of provision for the aged. Old age pensions certainly did make life easier for older workers in their struggle to survive; the payments, however, were never designed nor con-

4 Herta Wolff, Die Stellung der Sozialdemokratie zur deutschen Arbeiterversicherungsge. setzgebung von ihrer Entstehung an bis zur Reichsversicherungsordnung (Berlin, 1933), p. 37.

4s Bebel, "Das Gesetz uber die Invaliditäts- und Altersversicherung", p. 468.

46 Jbid., p. 467.

47 With one exception, the socialist members of the French parliament, too, accepred pension contributions from the workers' side. Their arguments reflected the minimalist position that a bad law to improve the workers' lot was better than no law at all. So the voting patterns of the socialist parliamentarians had common features in both countries. The debates, however, were different. 
sidered to be a kind of substitute wage. The situation of the aged in France was made more difficult by the fact that the pensions granted on the basis of the Retraites ouvrières et paysannes, which was passed by parliament only in 1910 and came into force a year later, were, with the exception of some cases governed by interim regulations, not paid out until decades later. However, pension schemes did exist in France during the nineteenth century. The Caisse nationale de retraite, founded in 1850 , served as a depository for factory workers' pension funds. The Mutualités (insurance cooperatives for self-help) also served as pension funds to a limited degree. The pensions granted by the Mutualités were not numerous and the amounts involved rather small. Moreover, such pensions were paid out on an irregular basis, depending on the financial situation, and there was no automatic right to claim. Around 1908 there were $120-130,000$ elderly persons who received a yearly pension of between 70 and 100 francs. These recipients were more likely to belong to the middle class than to the mass of workers. ${ }^{48}$ Apart from the miners and the railwaymen who had had their old age pension system since the 1890 s, by 1900 only 3 to 4 per cent of all workers could expect to receive an old age pension. This minority worked in large industrial firms and the pension accorded them was usually a company one. ${ }^{49}$ By 1936,62 per cent of all workers and all the self-employed continued to work after attaining retirement age. ${ }^{30}$ This proved that they had no financial resources to fall back on.

In comparison, the long period set down for old age pension eligibility ("insurance years") in Germany meant that the entire question of insurance for the elderly tended to lose significance because the conditions of eligibility shifted the actual date of retirement far beyond the legal pensionable age, thus reducing the numbers of those who were actually in receipt of a state pension.

Friedrich Kleeis, one of the SPD's leading experts on social policy, indicated that the regulations governing the insurance years needed for pension eligibility had become "increasingly unfeasible":

There are many insured persons who, because of long terms of unemployment, self-employment or other activites not covered by State insurance, have interrupted the insurance life-span for lengthy periods. ${ }^{31}$

As a result of such interruptions, many individuals on reaching their 70 th birthday did not fulfil the conditions for pension entitlement and could draw the pension only years later. The amount of pensions granted sank

48 Hatzfeld, Du Paupérisme à la Sécurité Sociale, p. 205.

49 Guillemard, Le déclin du social, p. 37.

so Jbid., p. 58.

st Friedrich Kleeis, "Die Abnahme der Altersrenten". Die Neuc Zeit, 24 (1906), pp. 69 72, esp. p. 70. 
between 1893 and 1905 - from 31,083 to 10,672 . In the same period there was a considerable increase in invalidity pensions $-35,177$ to $122,869 .{ }^{52}$

A nation-wide pension scheme to cover basic needs, the economic basis for a work-free retirement, seemed as distant a prospect as ever in both countries. How those affected reacted to this situation is of special interest, not least because of the range of views expressed.

Whereas in Germany the concept of a state pension which had to be topped up by other payments was accepted by all classes and the SPD, the goal of a pension sufficient to sustain even a minimum existence found expression within the French labour movement, albeit in very vague terms. This minimum requirement of according the elderly French worker a reasonable pension and a retirement in decency ("une existence médiocre et décente") was a demand frequently raised. Sometimes, as in a report on motions passed by the CGT and published in La Guerre sociale in 1909, a realistic framework was described:

It [CGT] considers that every worker who cannot work should be supported by a society which he has enriched and, rather than the defenders of bourgeois society, it is the producer no longer capable of producing who should live as if he were still working. ${ }^{53}$

If incapacity to work infused the CGT standpoint, Jaurès, in a parliamentary speech in 1911, spelt out the function he thought old age pensions should fulfil:

Gentlemen, we have not adequately defined the idea of the pension. The pension does not mean the relief of extreme distress [...] which could, so to speak, when added to other resources, prevent the old worker from dying of starvation. A pension, in the true sense of the word, in the normal sense of the word, means a sufficient amount to enable the old person, when his or her strength is gone, to maintain a decent and independent life, without outside let or hindrance, in the surroundings in which he has always lived. ${ }^{\text {st }}$

This definition leaves no doubt that, in the ideal case, old age pensions should guarantee the standard of living enjoyed hitherto, including financial independence for the old person who needs no other financial means than his pension.

Up to the inter-war period the various groupings in the French labour movement expressed this demand. This front included the CGT, now on a reform course, ${ }^{55}$ and the communist daily newspaper $L^{\prime}$ Humanité, which commented in 1936 on the results of an investigation into the standard of

32 Ibid., p. 69.

33 Maurice Harmel, "Les retraites ouvrières. Contre la capitalisation", La Guerre sociale, 2 (December 1909), p. 3.

^ Jean Jaurès, "L'amélioration de la loi des retraites. Discours de Jaurès, à la Chambre, le 16 décembre 1911", La revue socialiste (January 1912), pp. 1-26, esp. p. 9.

ss "[...] retiring permanently as part of a normal life" (A. Rey), in La question des Assurances sociales (Paris, 1925), p. 5. 
living among older workers "that those who have enriched themselves from the labour of all should pay the living costs and ensure us last years in dignity, which is our right, anyway". 56

Such an expectant attitude was not reflected in similar debates in Germany, where the postulate of life-long employment had lost none of its effectiveness. However, due to the critical economic developments during the Weimar Republic and their adverse consequences for the labour market, the first cracks appeared in the relatively rigid mental attitude to old age pensions in Germany. Rising unemployment among elderly workers led to a slow change in how old age was perceived: it was no longer primarily associated with infirmity and the loss of physical capacity, but that a phase in the life cycle without paid work was considered a possible and - because of the economic situation - necessary solution. ${ }^{57}$

Mass unemployment during the slump of the 1930s favoured French demands to allow mainly male workers of advanced age to retire and make way for the young. For example, after the communist deputy WaldeckRochet had promised elderly workers the unqualified support of the PCF (Parti Communiste Français), he closed his remarks with the following words:

We shall honour our commitment to stand shoulder to shoulder with you, to fight to the end, inspired by just one thought: to give work to the young and to ensure an honourable pension for all of France's workers in their old age. ${ }^{58}$

In PCF propaganda the idea of a "decent" old age pension was used explicitly as a panacea for the problems of the jobless: the pensions must be high enough to facilitate the opening of the labour market for young unemployed workers ("pour stimuler la décongestion du marché du travail et ouvrir les débouchés aux jeunes"). ${ }^{59}$

\section{LIFE-LONG WORK OR WELL-DESERVED LEISURE}

In contrast to Germany, the French demand that the elderly workforce should retire from paid employment was not such a radical break with cultural attitudes: the right of the old to rest and relaxation had a long

\section{Fernand Fontenay, La misère des vieux (Paris, 1937), p. 15.}

s7 See Gerd Göckenjan and Eckhard Hansen, "Der lange Weg zum Ruhestand. Zur Sozialpolitik fur das Alter zwischen 1889 und 1945", Zeitschrift fiir Sozialreform, 12 (1993), pp. 725-755.

${ }^{88}$ Waldeck-Rochet (Député de la Seine), "L'enrichissement des compagnies d'assurances par la ruine des petits épargnants", Cahiers du bolchevisme, 15/2 (1938), pp. 537-544, esp. p. 544.

${ }^{9}$ André Parsal (Député de la Seine). "La retraite aux vieux doit être avant la fin de l'année 1938", ibid., p. 532. And at the end of his speech: "Stay united, male and female citizens of advanced years, with the centainty which you and the whole country harbour, that your demands will be successful in obtaining for our France work for the young and bread for the aged" (p. 536). 
tradition in France from the time of the French Revolution, if not earlier. ${ }^{60}$ On the other hand, in the German discussion during the early decades of this century, the idea of old age as a phase when hard work was rewarded with work-free retirement played virtually no part. The legitimacy of relaxation in old age was recognized in France, and often formulated by drawing on the negative example of the German social system. The socialist Morizet defined in 1901 the decisive difference between the two systems:

The German law is not concerned to know whether it is necessary or legitimate to stop all work beyond a certain age [.. . ] It is only by a sort of derogation from its principles that it gives the seventy-year-old worker not a retirement benefit, but a life annuity reflecting the reduction of his strength and powers brought about by age. [...] The (French) authors' concept, on the contrary, is based on the right of all workers from a certain age to rest from their labours. ${ }^{6 t}$

La Vie socialiste demanded in 1904 that "retirement in old age should be granted to all". ${ }^{62}$ Likewise Le Socialiste, since 1905 the main newspaper of the united socialist party SFIO, formulated in 1908 that it was the right of the working class to be given "the opportunity to take things easy, safe from need, after having worked all those years when a man can work". 63

The PCF was still claiming in 1937 the right of the aged to retirement and rest. ${ }^{64}$ Such demands were not raised solely by the labour movement, but were shared by a broad cross-section of French society. ${ }^{65}$ None the less, France could not have been depicted as a paradise for old people with leisure time on their hands. Both the Enlightenment and the French Revolution had established work as the source of communal and personal happiness. In the middle of the nineteenth century, the middle classes and the emerging proletariat were at least united in their rejection of aristocratic leisure. Utopian ideas soon manifested themselves in connection with the evaluation of labour, promoting a notion of work which did not

* Plans put forward during the revolution for the happy family home, the ideal house in the country, included a separate room for the old folk which was decorated with the motto, "Rest in dignity after a life of labour": Bois, Les vieux de Montaigne, p. 246.

"André Morizet, "Les retraites ouvrières", Le Mowvement socialiste (August 1901), pp. 226-236, esp. p. 228.

62 François Foumier, "Retraites pour la vieillesse", La Vie socialiste (1904/1905), pp. 976987, esp. p. 976.

${ }^{63}$ A. Buckerère, “Assurance sociale”, Le Socialiste (December 1908), p. 1.

64 Fontenay, La misc̀re des vieıx, p. 9.

65 This demand was supported by Edouard Cheval, for example, in his Ph.D., which has a political and economic orientation: "The peasant, who had toiled all his life on his bare patch of ground to scrape enough to eat, the agricultural or industrial worker who, for years, has been bent over the same task monotonously repeating the same movements, as soon as they are weakened by age, can no longer find useful work. They should be able to end their days in a retirement which would be a fitting reward of a full life": Cheval, Les résultats pratiques de la loi du 15 juillet 1905, p. 4. For similar arguments see also $M$. Degas, Les Assurances sociales (Paris, 1924), p. 60. 
alienate the worker and transformed his labour from a source of misery to one of enjoyment (e.g. Fourier). ${ }^{66}$

In 1880, Paul Lafargue, French socialist and son-in-law of Karl Marx, wrote a polemic attacking the pathological and harmful "work-addiction" of the proletariat, and advocated a right to idleness and the reduction of the working day to a maximum of three hours:

But to convince the proletariat that the motto they have been infused with is perverse, that the limitless labour since the beginning of this century is the worst scourge which ever befell the human race, that work is only then scented with the pleasures of idleness, only becomes a useful passion for the human organism when it is prudently regulated and restricted to three hours daily at most - all that is a difficult undertaking. ${ }^{67}$

Lafargue built his argument around the thesis that the proletariat may on no account adopt the bourgeois work-ethic, that work is not just the only purpose in life, but, on the contrary, that it should be restricted as far as possible, so as to fend off its harmful consequences for the health and psychic state of the workers. His radical, provocative and exaggerated plea may have caused controversy in the French labour movement as well; for our purposes, however, the reaction to it in Germany is far more interesting. Significantly, his "Right to Idleness" appeared originally in the supplement of Sozialdemokrat; ${ }^{*}$ and was later published as a brochure in Zürich (1887) and Berlin (1891). Eduard Bernstein provided the translation and wrote in the foreword to the 1887 edition that "from various sources I have heard the concern that it [the brochure] will be misunderstood, the title itself suffices to create bad feeling". ${ }^{68}$ In conclusion Bernstein expressed the hope "that even he who will read the piece with apprehension, may its 'morality' or 'immorality', whichever you like, succeed in stimulating his thoughts". ${ }^{69}$

This uneasiness about possible reactions among German readers was justified, as Lafargue's ideas were diametrically opposed to the work-ethic rooted in the German workforce. What is more, in his translation Bernstein attempted to play down the tone and meaning of the pamphlet. ${ }^{70}$ For example, he replaced Lafargue's demand for a three-hour day with the phrase that work must "be sensibly regulated" and "reduced to a level appropriate to society's requirements". ${ }^{71}$ Bernstein went so far as to omit

${ }^{60}$ See the introduction to Wolfgang Asholt and Walter Fähnders (eds), Arbeit und Majpiggang 1789-1914: Dokumente und Analysen (Frankfurt/Main, 1991), pp. 9-19.

${ }^{67}$ Paul Lafargue, "Das Recht auf Faulheit. Widerlegung des 'Rechts auf Arbeil' von 1848", in Jan Pätzold (ed.), Paul Lafargue: Das Recht auf Faulheit und andere Satiren (Berlin, 2nd ed., 1991), pp. 7-53, esp. p. 26.

os Ibid, p. 129.

69 Ibid., p. 130.

70 For details of the changes made in translation see Emst Benz, Das Recht auf Faulheit oder Die friedliche Beendigung des Klassenkampfs (Stuttgart, 1974), esp. pp. 60-73.

"Ibid., p. 63. 
the second part of the brochure's title, "A Refutation of the Right to Work Demand of 1848". According to Bernstein, the call for a three-hour working day would overtax the imaginative capacity of a German Social Democrat and perhaps shock his moral sensibilities into the bargain. ${ }^{72}$

In similar manner, Karl Kautsky, too, dealt with "the right to idleness", which he ultimately equated with the claim for a normal working day of eight hours. "One should not be so shocked by 'Right to Idleness'. It is nothing new or outrageous. [. . .] The workers and serious-minded social reformers everywhere have been fighting for 'the right to idleness', for a normal working day, for at least twenty years, in some countries for even longer."73

The high esteem in which paid work was held ${ }^{74}$ in the German labour movement is one of the main reasons why there was little meaningful discussion about a work-free period of rest in old age. Such a phase was not seen even in eventual or utopian terms, but only in cases of emergency - unfitness for work for reasons of health. The social democratic social policy expert Friedrich Kleeis argued that a pension for able-bodied .workers would seem "like a present", and that, "despite due respect for the old", was not desirable. ${ }^{73}$ The notion that a worker had by virtue of his labour the right to a secure income in his old age was foreign to German labour circles. As an adherent of the conventional German wisdom in this question, Heinrich Molkenbuhr warned of the dangers of unfair treatment if the pension age were to be lowered under 70 years: in such a case persons who had "a less strenuous occupation" would be at an advantage, providing, of course, that they were not invalids already. Instead, the invalidity pension scheme, linked not to an age limit, but designed for emergency situations caused by the incapacity to work, should be extended. ${ }^{76}$ The French demands for a pension as compensation or reward strengthened claims that old age pensions were a right, but provoked no echo in Germany, where such thinking was discouraged."

Up to and including the Weimar period German society put great value on job activity, including skilled or professional work. The class-conscious proletariat was expected to have a positive attitude to work, specifically because it carried the responsibility for society in the years to come, as

72 Why he ignored the phrase "Die Widerlegung des Rechts auf Arbeit" (a refutation of the right to work) is not clear, as Kautsky had criticized this demand in 1884: as a demand of petit-bourgeois socialists, who strive for an idealized copy of present society, forgetting that the right to work could eventually tum into the right to the workhouse: Karl Kautsky, "Das Recht auf Arbeit", Die Neue Zeit (1884), pp. 299-303, esp. pp. 299-300.

${ }^{73}$ Ibid., p. 303.

74 See the comprehensive study by Joan Campbell, Joy in Work, German Work: The National Debate, 1800-1945 (Princeton, 1989).

75 Friedrich Kleeis, "Herabsetzung des Lebensalters fur den Bezug von Altersrente?", Arbeiter-Versorgung (1906), p. 65.

${ }^{76}$ Molkenbuhr, "Zum französischen Altersversicherungsgesetzentwurf", pp. 493-494.

" Gockenjan and Hansen, "Der lange Weg zum Ruhestand". 
the SPD and the trade unions argued. "But it is also correct that it is only the working-class which carries the future on its shoulders and must be imbued with this mission; it must, as a class, possess a completely different moral character than that of the bourgeoisie which sees its ideals submerging into the past. The workers should always bear those words in mind which Lassalle directed at them: "No longer do the vices of the oppressed befit you, nor the idle diversions of the mindless, or even the harmless recklessness of the insignificant. You are the rock on which the modern church is to be built."

In this article (Sozialistische Monatshefte, 1922), the author, Bruno Borchardt, went so far as to suggest to workers of both sexes that they should improve their work discipline in order to rebuild the country, thereby giving the ruling classes a good example. "At the moment, reforming the idea of work discipline is an important, if not the most important service to the people."79

This call to take a full part in post-war reconstruction was not a German speciality, however. After the end of World War II, Maurice Thorez, General-Secretary of the PCF, proclaimed that "to produce, produce and to produce still more, to mine coal, is today the highest form of class duty, of your duty as a Frenchman. Yesterday, sabotage was the weapon, but today the miner's weapon is production in order to defeat reaction, to show class solidarity with the workers in other branches of industry." 80

The idea of work as a central value in human existence - the joys of labour - was an import of Soviet "workerist" (Stakhanovite) ideology already adopted by the PCF in the 1930s. ${ }^{81}$ Appeals for a positive cast of mind towards the work process, for a new work-ethic in Germany, ${ }^{82}$ were supplanted by deliberations which originated in the effects rationalization was having on job satisfaction and professional codes of ethics. In an article in the trade union journal Die Arbeit (1926), Bruno Rauecker emphasized that new forms of work-organization called for "physical and mental re-adjustment of the most serious kind". He continued:

While the American labour force has been used for decades to considering work wholly as a means to an end, as an opportunity to eam money, the broad masses of European workers do not yet share this exclusively mercantile attitude. For

"Bruno Borchardt, "Einige Worte zur Arbeitsmoral", Sozialistische Monatshefte (1922), pp. 784-790, esp. p. 784.

79 Ibid., p. 790.

${ }^{80}$ Maurice Thorez, speech of 21 July 1945, cited in Marc Lazar, "Damné de la terre et homme de marbre: L'ouvrier dans l'imaginaire du PCF du milieu des années trente $a$ la fin des années cinquante", Annales ESC (September-October 1990), pp. 1071-1096, esp. p. 1082.

81 Lazar interprets this attitude as a consequence of the Stakhanov cult in the Soviet Union: Lazar, "Damne de la terre", p. 1078.

${ }^{82}$ Otto Hessler, "Die Stellung der Jugendlichen zum Beruf und der Arbeit", Gewerkschaftsarchiv (1926), pp. 258-261, esp. p. 259. 
them work has a moral content central to their lives, it is both duty and responsibility, against which they can measure their skills and moral strength, even in situations where industrial work practices allow the individual to carry out only a portion of the job in hand. [...] The German worker, tending more than any other European counterpart to a spiritual frame of mind, will suffer most from this development. He will not be inclined to give up without protest the creative possibilites of his skill which he does not find in automated work processes. He will continue to seek a replacement for the psychological satisfaction his trade had given him in years gone by. ${ }^{83}$

Rauecker believed that social policies would now have to absorb and alleviate the negative results of automatization and rationalization by offering the worker leisure activities, so that the individual worker could preserve his strength "as far as possible". ${ }^{84}$

Free time and how it was utilized are seen in this context as a compensation for the fact that it was no longer possible to fulfil oneself at the workplace. The above quotation also demonstrates the adherence to old craft traditions, with their characteristic guild pride. Explicit is also the writer's intention to imbue the most alienating forms of work with a higher moral value, attributing to labour, now as before, a form of "spiritual bonding". The formulation of a new work-ethic was propagated as a goal of trade union policy.

Work becomes social obligation, it is toil and misery, but infuses the source of all values. We proudly declare our faith in the proletariat which creates all values. The sense of social obligation is the earth in which work is rooted and can thrive. ${ }^{85}$

Worlds lie between the concept of work seasoned with leisure and the ideal of human labour as ethically motivated toil. Although Eims, the writer of the article quoted from above (Gewerkschaftsarchiv), supported the demand to liberate work from the chains of capitalist production, the consequences of his arguments and ideals for future society continued to concentrate on a form of work which would finally bring happiness to all mankind. ${ }^{86}$ However, toil and drudgery, as intrinsic to work, remained central to the debate.

The German side of the discourse, then, was hardly fertile ground for nourishing plans of work-free retirement in old age. A suitable climate seemed to exist in France for such deliberations, at least in the early part of this century. Financial security which enabled the individual to retire and live a comfortable existence, was held by the workers, but also by the middle classes, who were more likely to realize this ideal, to be the goal

${ }^{33}$ Bruno Rauecker, "Rationalisierung und Atbeiterkultur", Die Arbeit (1926), pp. 115122, esp. p. 117.

Ibid., p. 122.

8s Rudi Eims, "Die Krise der Arbeit: Entwicklungsgeschichtliche Betrachtungen", Gewerkschaftsarchiv (1928), pp. 259-264, esp. p. 263.

${ }^{26}$ Ibid.. p. 264. 
of a successful life plan. On the other hand, a pension which covered the needs of the aged was an acceptable alternative for those who lacked savings or wealth. Sombart's argument that the slower rate of industrialization in France than in Germany led to the conservation of pre- or early capitalistic ways of life in France ${ }^{87}$ falls short of the mark and suggests simply that France was backward. Not only did the varying degrees of change which were imposed on the French social structure generate deviant opinion, cultural attitudes handed down over generations also led to reactions different from those voiced in Germany, although both countries were confronted with similar problems. In the first half of this century France, too, developed into an industrial, "working" society where rationally organized forms of production demanded discipline and a work-ethic from the labour force. None the less, as has been shown, the labour movement of France and Germany did not pursue the same questions, and in discussions about a work-free phase of life, formulated quite dissimilar demands.

It would be wrong, of course, to paint a paradisical picture of French conditions, with young and old striving in unison for a period of idleness or having no problems in coming to terms with a life without work. Both German and French society were characterized by the general failure to envisage enjoying time off or retirement as liberation from strenuous work. It is no accident that the French labour movement, in demanding retirement, never spelt out how this period could be meaningfully spent. Instead, the post-pension life cycle was seen as what followed the welldeserved and much longed for abolition of an alienated labour relationship, a secure old age which would invent its own positive activities, so to speak. Thus, the enforcement of old age provisions in both countries during the post-war era was accompanied by an identity crisis on the part of the retired population.

"Werner Sombar, Der moderne Kapitalismus, vol. II/l (Leipzig, 1917), p. 56, where he described the pensioner ideal as "characteristic of early capitalist economic thinking". 